\title{
Head and neck cancer: validation of a data collection instrument
}

\author{
Câncer de cabeça e pescoço: validação de instrumento para coleta de dados \\ Cáncer de cabeza y cuello: validación de instrumento para la recolección de datos
}

\begin{abstract}
Andrea Bezerra Rodrigues', Gilmara Holanda da Cunha', Caroline Batista de Queiroz Aquino', Suzy Ramos Rocha', Cláudia Rayanna Silva Mendes', Mariana Alves Firmeza', Alex Sandro de Moura Grangeiro"

' Universidade Federal do Ceará. Fortaleza, Ceará, Brazil.

" Universidade Federal da Paraíba. João Pessoa, Paraíba, Brazil.
\end{abstract}

How to cite this article:

Rodrigues AB, Cunha GH, Aquino CBQ, Rocha SR, Mendes CRS, Firmeza MA, et al.

Head and neck cancer: validation of a data collection instrument. Rev Bras Enferm [Internet]. 2018;71(4):1899-906.

DOI: http://dx.doi.org/10.1590/0034-7167-2017-0227

Submission: 04-18-2017 Approval: 08-09-2017

\section{ABSTRACT}

Objective: construct and validate the content of an instrument to collect data from patients with head and neck cancer (HNC) served in a specialty clinic. Method: methodological study consisting of four steps. The first step consisted in the preparation of the instrument using databases and the theoretical model of Marjory Gordon. In the second and third steps the content was validated by eight nursing judges. The evaluation used the Content Validity Index (CVI). The fourth step consisted in a pilot test with seventeen HNC patients. Results: of the 88 questions formulated and organized on the dimensions of structure and process submitted to validation, items with CVI lower than 0.80 were excluded. The final instrument was composed of 56 items, with global CVI calculated as 0.87. Conclusion: the final instrument presented content validity for data collection in head and neck clinic.

Descriptors: Validation Studies; Nursing; Nursing Care; Head and Neck Neoplasms; Hospital Outpatient Clinic.

\section{RESUMO}

Objetivo: construir e validar conteúdo de um instrumento para levantamento de dados de pacientes com câncer de cabeça e pescoço (CCP) atendidos em ambulatório da especialidade. Método: estudo metodológico composto por quatro etapas. A primeira consistiu na elaboração do instrumento, utilizando-se bases de dados e o modelo teórico de Marjory Gordon. Na segunda e terceira etapas ocorreu a validação de conteúdo por oito juízes enfermeiros. Para avaliação foi utilizado o Índice de Validade do Conteúdo (IVC). Na quarta etapa foi realizado teste piloto com dezessete pacientes com CCP. Resultados: das 88 questões formuladas e organizadas nas dimensões de estrutura e processo submetidas à validação, foram excluídos os itens com IVC menor que 0,80. O instrumento final foi composto por 56 itens, obtendo-se cálculo de IVC global de 0,87. Conclusão: o instrumento final apresentou validade de conteúdo para a coleta de dados em ambulatório de cabeça e pescoço.

Descritores: Estudos de Validação; Enfermagem; Cuidados de Enfermagem; Neoplasias de Cabeça e Pescoço; Ambulatório Hospitalar.

\section{RESUMEN}

Objetivo: construir y validar el contenido de un instrumento para la recolección de datos de los pacientes con cáncer de cabeza y cuello (CCC) tratados en la especialidad ambulatoria. Método: estudio metodológico compuesto por cuatro etapas. La primera consistió en la elaboración del instrumento, utilizando bases de datos y el modelo teórico de Marjory Gordon. En la segunda y tercera etapas ocurrió la validación de contenido por ocho jueces enfermeros. Para la evaluación se utilizó el Índice de Validez del Contenido (IVC). En la cuarta etapa se llevó a cabo una prueba piloto con diecisiete pacientes con CCC. Resultados: de las 88 cuestiones formuladas y organizadas en las dimensiones de estructura y proceso sometidas a la validación, se excluyeron los ítems con IVC menor que 0,80. El instrumento final tuvo 56 ítems, obteniéndose cálculo de IVC global de 0,87. Conclusión: el instrumento final presentó validez de contenido para la recolección de datos en ambulatorio de cabeza y cuello.

Descriptores: Estudios de Validación; Enfermería; Atención de Enfermería; Neoplasias de Cabeza y Cuello; Servicio Ambulatorio en Hospital. 


\section{INTRODUCTION}

Head and neck cancer represents $3 \%$ of all types of malignant neoplasms. The incidence of the disease has increased in recent years and the treatment often leads to sequelae in patients, with impairment in nutritional, phonatory, and breathing aspects, in addition to psychological problems ${ }^{(1-3)}$.

The nurse has a key role in care, organizing their work through the application of the nursing process (NP), which involves five interrelated and dynamic steps: investigation, diagnosis, planning, implementation, and evaluation. In the first step, a systematic data collection plan is used to determine problems and, based on them, nursing diagnoses (ND) are defined, which corresponds to the second step of the process and supports the preparation of the care plan ${ }^{(4-5)}$. By applying the NP steps nurses obtain resources and become able to understand the multidimensionality of the individual and list the priorities, aiming at optimizing the time and the quality of care ${ }^{(6)}$.

Validating an instrument is a method to analyze the accuracy of a particular inference drawn through scores of a test, representing more than the expression of the value of a measuring instrument. It is an investigation that permeates the entire process from the preparation, application, correction, and interpretation of results. Validating the content consists in investigating if it responds to every aspect of its object, observing it as to the relevance of the objectives to be measured $^{(7)}$.

\section{OBJECTIVE}

To construct and validate the content of a data collection instrument for HNC patients served in a specialty clinic.

\section{METHOD}

\section{Ethical aspects}

The study was approved by the Research Ethics Committee of the hospital of the study and obtained Certificate of Presentation for Ethical Assessment. Participants involved in the pilot test signed an informed consent. The ethical principles for research with human beings were followed, based on Resolution No. $466 / 2012$ of the National Health Council ${ }^{(8)}$.

\section{Study design, location, and period}

This is a methodological study consisting of four steps. The first step is related to the construction of the instrument, the following two steps comprise the first and second round of instrument content validation, respectively, by the judges, and the fourth step corresponds to the pilot test.

For the construction of the instrument we selected the theoretical and methodological framework of Marjory Gordon and carried out a search in the databases Medical Literature Analysis and Retrieval System Online (Medline), Latin American and Caribbean Health Sciences Literature (Lilacs), and Database on Nursing (BDENF). We consulted, in parallel, sites of specific associations of oncology, two international ones, Oncology Nurses Society (ONS) and American Society of Clinical Oncology (Asco), and a national one, National Cancer Institute (Inca). The search resulted in a total of 39 publications, addressing the main issues: changes in taste, hearing, smell, nutrition, breathing, communication, psychosocial and spiritual changes, themes considered relevant in the making of the preliminary version of the instrument.

The instrument construction and validation steps were carried out from April to November 2015. The fourth step, referring to the pilot test with patients served in the head and neck clinic of a University Hospital in the city of Fortaleza (CE), was carried out from February to April 2016.

\section{Study protocol}

The instrument construction process, referring to the first step, was based on the theoretical and methodological framework of Marjory Gordon, the functional theoretical model, which comprises questions organized by domains. Gordon shows that a functional health pattern evolves from the user-environment interaction. Each pattern is an expression of the biopsychosocial integration, and cannot be understood without knowledge of the other patterns. A functional pattern represents a healthy set of behaviors, in counterpoint to a dysfunctional health pattern, described by the nursing diagnosis, which can occur in disease ${ }^{(9)}$. As a methodological framework for construction we adopted the content validation model of Pasquali ${ }^{(10)}$.

Also in the first step a review of publications was conducted to determine the measurable indicators based on search on the databases using the Health Science Descriptors and Medical Subject Headings (DECs/MeSH): "enfermagem" (nursing), "diagnóstico de enfermagem" (nursing diagnosis), "quimioterapia" (drug therapy), "radioterapia" (radiotherapy). We used the controlled descriptor "neoplasias de cabeça e pescoço" (head and neck neoplasms), associated through the Boolean operator AND to the abovementioned descriptors. We considered the works published from 2010 to 2015 provided in full.

The first version of the instrument was composed of 88 items, with questions organized by domains, namely: health promotion, nutrition, elimination and exchange, activity/rest, perception/ cognition, self-perception, roles/relationship, sexuality, coping/ stress tolerance, life principles, safety/protection, and comfort.

The second step, referring to the first round of the instrument content validation, followed these steps:

a) selection of judges: there is no consensus on the optimal number of judges, but some authors argue that at least five are necessary, while others, six judges. Having more than five judges facilitates the detection and exclusion of wrong variables $^{(11)}$. Therefore, this study followed the recommendation of at least five judges. The difficulty in selecting experts is considered a critical point in validation studies, and generally occurs in relation to academic title, specialized knowledge, and sample size. This may be related to the availability of professionals with the desired established expertise and power of representation ${ }^{(12)}$, which occurs specifically in this area of specialty (head and neck cancer). Thus, five experts were established, considering the difficulty to find nurses with the required expertise at the time of data collection. However, with recruiting by the method of snowball sampling, a total of eight judges was obtained.

The eight participating judges met the judge selection criteria established by Fehring ${ }^{(13)}$, which sets a minimum score of five, according to the following items: doctoral degree (4 
points), master's degree (3 points), own thesis on the subject of the construct (2 points), own dissertation on the subject of the construct ( 2 points), having practice (clinical, education, research) on the area of the construct (2 points). We submitted a letter, specifying the evaluation criteria and the request for assessment; a copy of the proposed data collection instrument, and a form for assessment of each item. The material was presented personally to two judges and sent by mail to six of them. The assessments returned to researchers after about 60 days.

b) analysis of the degree of agreement: the judges were asked to assess the instrument as to the relevance and representativeness of the items, and the answers were considered on a Likert-type scale ranging from 1 to 4 , where 1 considered the item not relevant or not representative; 2 , required major revision to be representative; 3 , required little revision to be representative; and 4, the item was considered relevant or representative.

The third step, referring to the second round of instrument content validation, occurred because, after the first round of assessment by the judges, we excluded 32 items that did not reach the minimum Content Validity Index (CVI) of 0.80; thus, we decided to conduct a second round of assessment. Accordingly, the instrument composed of 56 items, already including the suggestions of the judges, was again submitted to them for assessment. The CVI was calculated again, and all items reached more than 0.80 . The assessments returned to researchers after about 30 days.

The fourth step referred to the pilot test conducted with patients served in the head and neck clinic.

\section{Sample, inclusion criteria, and exclusion criteria}

After the validation process with the judges, the instrument was applied by three trained interviewers who followed a standard operational procedure developed by the authors, containing conceptual and operational definitions. The sample was designed based on the records of patients registered in the head and neck clinic, considering the confidence level of $95 \%$ and sampling error of 5\%, which resulted in 167 users of the service. Considering that it is a pilot study and, to this end, a percentage of approximately $10 \%$ is suggested ${ }^{(14)}$, seventeen patients participated, who were selected for convenience in the head and neck clinic in the days of collection.

To evaluate the understanding of participants and to measure the time of application of the instrument we performed a content analysis of the reports from the trained interviewers as to the difficulties of understanding of the questions by patients. We registered the collection start time and end time on the instrument itself, enabling the estimation of the time of application.

\section{Analysis of results and statistics}

The data compilation was performed in Excel software and data analysis was performed in the Statistical Package for Social Sciences (SPSS) version 21. We calculated the mean CVI for the items considered relevant, adopting a CVI of 0.80 or higher, that is, the equivalent of $80 \%$ agreement between the judges, which is considered optimal(15), and items that did not reach this value were discarded. In addition, we considered all the suggestions of the judges. The CVI was calculated using the sum of the number of answers marked " 3 " or " 4 " by the judges, divided by the total number of answers.

\section{RESULTS}

The first version of the instrument was prepared with support of the studies found in the selected databases. The so-called Instrument for Nursing Investigation by Functional Patterns for Head and Neck Clinic was composed of 88 items.

Of the eight judges who assessed the instrument, most were female $(87.5 \%)$, with long experience in the Oncology area between eleven and twenty years (75\%), doctoral degree in the area of interest of the construct $(62.5 \%)$, current activity in teaching $(87.5 \%)$, bibliographic production on the subject (75.0\%), and aged $26-55$ years (mean \pm standard deviation: $43.25 \pm 10.88$ ). All evaluators $(n=8 / 100 \%)$ had experience in Oncology, and $37.5 \%$ had parallel experience in nursing diagnosis.

Of the 88 items that were part of the original version of the instrument, 32 items of different domains were excluded due to not reaching the $0.80 \mathrm{CVI}$. The remaining set of 56 items reached mean $\mathrm{CVI}$ of 0.94 , ensuring the content validity and the representativeness of the nursing data collection instrument in the target population.

The 32 items excluded were: medical diagnosis; If you have misconceptions about the disease/treatment and which; willingness to comply with the proposed treatment in the future; If you have Ileostomy; If you need saline therapy, hydration of skin and mucous membranes; abdominal propaedeutics; arterial blood gas analysis; diaphoresis; If you need medications to sleep; Glasgow Coma Scale; pupillary reaction; susceptibility testing; use of opioids; willingness to learn; self-description of the patient; If verbalizes hopelessness; If verbalizes loss of control; how is the relation with others; If verbalizes feeling alone; effects of surgery/ treatment on your self-esteem and life; report of stress factors; physical manifestations of stress; ways to manage the problems; available support systems; religion is reported; what would you like to do in the near future; use of immunosuppressive medications; values of leukocytes and neutrophils; complaint of pain; and complaint of nausea. It should be noted that the latter two reached $\mathrm{CVI}$ of 0.63 each, as they were in the comfort domain, and the judges proposed that they were changed to the perception/cognition and nutrition domains, respectively; thus, they reached higher CVI than 0.80 in the second round of validation.

Table 1 shows the distribution of the individual content validity indices of items that remained (56) after the second round, according to the analysis of the judges for each domain.

For some items the judges suggested changes, which were implemented. In item 3 they proposed the addition of oncologic history. In other questions the suggested changes referred to the form of presentation, that is, there was suggestion to combine items, as in the case of "volume and interval of enteral diet", which was combined with "type of enteral diet". They suggested relocating the item "pain" to the Perception/Cognition domain, and adding the information "type of pain, location of pain, degree of pain, scale used, and drug treatment for pain". The question "how long has had the pain", which reached CVI of 0.88 , was 
also combined with the item "pain", at the suggestion of the judges. Another change suggested by the judges was related to the item "complaint of nausea", which, as requested, was relocated to the Nutrition domain. It was also requested that, in the Perception/Cognition domain, the term "mental state" was replaced by "level of consciousness". While in the Elimination and Exchange pattern they suggested the addition of the item "Elimination-related devices" in intestinal elimination.

Table 1 - Distribution of the Content Validity Indices according to the analysis of the judges, Fortaleza, Ceará, Brazil, 2016

\begin{tabular}{|c|c|c|}
\hline Domains & Items of the instrument & CVI* \\
\hline Health Promotion & $\begin{array}{l}\text { 1. Complaint } \\
\text { 2. Summary/Current disease } \\
\text { 3. Clinical/personal/family/oncology history } \\
\text { 4. Knowledge about disease/treatment } \\
\text { 5. Medicines (those they know they use) } \\
\text { 6. Compliance with current treatment (if any) and way of adherence } \\
\text { 7. Are there side effects of the medication? Which ones? } \\
\text { 8. Smoking/alcohol use/drug use } \\
\text { 9. Allergies }\end{array}$ & $\begin{array}{l}0.88 \\
1.00 \\
0.88 \\
1.00 \\
0.88 \\
0.88 \\
1.00 \\
1.00 \\
0.88\end{array}$ \\
\hline Nutrition & $\begin{array}{l}\text { 10. Weight/Height/BMI** } \\
\text { 11. Recent change in weight } \\
\text { 12. Type of diet, volume and interval of enteral diet } \\
\text { 13. Mastication } \\
\text { 14. Dental prosthesis } \\
\text { 15. Swallowing } \\
\text { 16. Nausea } \\
\text { 17. Vomit } \\
\text { 18. Fluid intake } \\
\text { 19. Recent tests and their results }\end{array}$ & $\begin{array}{l}1.00 \\
1.00 \\
0.88 \\
0.88 \\
0.88 \\
1.00 \\
0.88 \\
0.88 \\
1.00 \\
0.88\end{array}$ \\
\hline Elimination and Exchange & $\begin{array}{l}\text { 20. Urinary elimination } \\
\text { 21. Intestinal elimination } \\
\text { 22. Skin integrity } \\
\text { 23. Drain } \\
\text { 24. Elimination-related devices }\end{array}$ & $\begin{array}{l}1.00 \\
1.00 \\
1.00 \\
1.00 \\
1.00\end{array}$ \\
\hline Activity/Rest & $\begin{array}{l}\text { 25. Physical limitation } \\
\text { 26. Motor strength } \\
\text { 27. Requires help to } \\
\text { 28. Caregiver/Degree of kinship } \\
\text { 29. Habit of exercise } \\
\text { 30. Pulmonary propaedeutics } \\
\text { 31. Cardiovascular propaedeutics } \\
\text { 32. Sleep/Rest } \\
\text { 33. Has self-care deficit? }\end{array}$ & $\begin{array}{l}1.00 \\
1.00 \\
1.00 \\
0.88 \\
1.00 \\
1.00 \\
1.00 \\
1.00 \\
1.00\end{array}$ \\
\hline Perception/Cognition & $\begin{array}{l}\text { 34. Level of consciousness } \\
\text { 35. Impaired speech } \\
\text { 36. Impaired memory } \\
\text { 37. Reads/Writes } \\
\text { 38. Pain, type of pain, pain location, how long has had the pain, degree of pain } \\
\text { (with the scale used), and drug treatment for pain } \\
\text { 39. Sight/Hearing/Taste/Smell } \\
\text { 40. How do you feel about your health problem? } \\
\text { 41. Did you notice any change of mood after the treatment? }\end{array}$ & $\begin{array}{l}0.88 \\
1.00 \\
0.88 \\
0.88 \\
0.88 \\
1.00 \\
0.88 \\
0.88\end{array}$ \\
\hline Roles/Relationship & $\begin{array}{l}\text { 42. Marital status } \\
\text { 43. Most important responsibilities in the current life situation } \\
\text { 44. Financial support }\end{array}$ & $\begin{array}{l}1.00 \\
0.88 \\
0.88\end{array}$ \\
\hline Sexuality & $\begin{array}{l}\text { 45. Sexual activity } \\
\text { 46. Physical or disease-related difficulties for sex } \\
\text { 47. Women/Gynecologic history } \\
\text { 48. Men/Urologic history }\end{array}$ & $\begin{array}{l}1.00 \\
0.88 \\
0.88 \\
0.88\end{array}$ \\
\hline Coping/Tolerance to stress & 49. Family system support for problems & \\
\hline Life Principles & $\begin{array}{l}\text { 50. Spirituality/Religion } \\
\text { 51. If not, do you have a belief or faith to help deal with the problems? } \\
\text { 52. How would you like to be helped }\end{array}$ & $\begin{array}{l}0.88 \\
1.00 \\
1.00\end{array}$ \\
\hline Safety/Protection & $\begin{array}{l}\text { 53. Peripheral venous catheter/Central venous catheter/Surgery incision/Tracheostomy } \\
\text { 54. Use of diuretic medications, vasodilators, anxiolytics, benzodiazepines } \\
\text { 55. Temperature in the last } 24 \text { hours }\end{array}$ & $\begin{array}{l}0.88 \\
0.88 \\
1.00 \\
0.88\end{array}$ \\
\hline
\end{tabular}


In the instrument pilot test step with the target population $(n=17)$, it was observed that most participants declared being married $(n=9 ; 52.9 \%)$ and of the Catholic religion $(n=12$; $70.5 \%)$. The most frequent location of the HNC was the parotid $(n=3 ; 17.6 \%)$. In this process, we observed a need to include the medical diagnosis in the instrument, which was in the preliminary version and was removed due to the judges' justification that it should already be in the medical record. However, it was not observed in practice during the pilot test.
We also observed the need to include some demographic data (age, sex, and educational level), since these data were only in the admission form, which made them difficult to obtain due to the dynamics of the clinic.

After the pilot test, the researchers who applied the instrument were questioned about possible difficulties of understanding by the patients. The interviewers who applied the instrument considered it adequate, without need for adjustments at that time. Chart 1 shows the final validated instrument.

Chart 1 - Instrument for Nursing Investigation by Functional Patterns for Head and Neck Clinic, Fortaleza, Ceará, Brazil, 2016

\section{Instrument for Nursing Investigation by Functional Patterns for Head and Neck Clinic}

Age: Sex: ( ) M ( ) F Medical Diagnosis: Educational level:

\section{Health promotion:}

Complaint:

Summary/Current disease:

Clinical/personal/family history:

Knowledge about disease/treatment: ( ) Yes ( ) No

Medicines (those they know they use)

Compliance with current treatment (if any): ( ) Yes ( ) No

Side effects of the medication? ( ) Yes ( ) No Which?

Smoking/alcohol use/drug use: ( ) Yes ( ) No. Specify:

Allergies: ( ) Yes ( ) No Which?

\section{Nutrition}

Weight: Height: BMI: Recent change in weight? ( ) Loss ( ) Gain Type of diet: Mastication: Dental prosthesis? ( ) Yes ( ) No Swallowing: Recent tests/results:

\section{Elimination and Exchange}

Urinary elimination: Intestinal elimination: Skin integrity: Drains:

Elimination-related devices:

\section{Activity/Rest}

Physical limitation: Motor strength:

Has self-care deficit? ( ) Yes ( ) No Requires help to:

Caregiver/Degree of kinship: Habit of exercise: ( ) Yes ( ) No

Pulmonary propaedeutics: Cardiovascular propaedeutics:

Sleep/Rest:

\section{Perception/Cognition}

Level of consciousness: Impaired speech: ( ) Yes ( ) No Impaired memory: ( ) Yes ( ) No

Reads (1) / Writes (2): 1 ( ) Yes ( ) No / 2 ( ) Yes ( ) No

Pain, type of pain, location of pain, how long has had the pain, degree of pain (with the scale used), and drug treatment for pain:

Sight/Hearing/Taste/Smell - Presents alteration? ( ) Yes ( ) No How do you feel about your health problem? Did you notice any change of mood after the treatment? ( ) Yes ( ) No

\section{Roles/Relationship}

Marital status: ( ) Single ( ) Married ( ) Widowed ( ) Stable cohabitation

Most important responsibilities in the current life situation: Financial Support:

\section{Sexuality}

Sexual activity: ( ) Yes ( ) No Physical or disease-related difficulties for sex: ( ) Yes ( ) No

Women/Gynecologic history: ( ) Yes ( ) No Men/Urological history: ( ) Yes ( ) No 


\section{Coping/Tolerance to stress}

Family system support for problems:

\section{Life Principles}

Spirituality/Religion:

How would you like to be helped?

\section{Safety/Protection}

Peripheral venous catheter/Central venous catheter/Surgery incision/Tracheostomy

Use of diuretic medications, vasodilators, anxiolytics, benzodiazepines

Temperature in the last 24 hours

Complaint of fatigue, degree of fatigue, frequency of fatigue

\section{DISCUSSION}

The instrument initially prepared with 88 items was modified after validation with the judges and test pilot with the target population, reaching a final format with 56 items. It must be taken into consideration that the nursing consultation in outpatient regime is an effective strategy, favoring the approach and the construction of an interpersonal relationship of help, in which nursing care management implies recognizing and meeting the needs of both patient and family ${ }^{(16)}$. Therefore, it should be noted that a data collection instrument should be complete and easy to understand, otherwise there can be failures or omissions. It was found that the average time for application of the instrument in the pilot sample was approximately thirty minutes.

While the number of hospital admissions is decreasing worldwide, it is estimated that outpatient consultations should increase to more than 1 billion per year. The American Academy of Ambulatory Care Nursing (AAACN) and the Collaborative Alliance for Nursing Outcomes (CALNOC) are leading collaborative organizations in fostering the quality of ambulatory care. The original structure of ambulatory care proposed by the AAACN and published in 1998 covers three main concepts: patient, environment, and nurse. Inherent in the concept of patient is the idea that each individual is unique, functioning holistically. The second concept (environment) aids in defining the practice of ambulatory nursing, situating it away from other specialties. And the third concept defines the nursing professionals by their dynamism and use of the nursing process in their role of specific specialty ${ }^{(17-18)}$.

To this end, data collection instruments are fundamental as they represent the first step of the nursing process. The construction of an instrument using the functional pattern model enables accessing data that are relevant for the nurse. In addition to the validation with the judges, which showed excellent value for general CVI (0.87) and for items (ranging between 0.88 and 1.00), the instrument includes necessary information for evaluation of the patient in ambulatory follow-up for head and neck cancer.

The HNC, due to the anatomical location, can cause significant changes in vital functions related to food consumption, communication, and social interaction of affected individuals, which may generate distress, both for patients and for their family members, usually leading to some degree of dysfunction in daily life ${ }^{(19)}$. In fact, in this study the items considered valid and representative by the judges involved all these spheres of change.

The judges considered relevant the item "smoking and alcohol use" $^{\prime \prime}(\mathrm{CVI}=1.0)$, which is consistent with the research findings according to which smoking and alcoholism have addictive factor and remain the main risk factors for the development of head and neck cancer ${ }^{(20)}$. This fact denotes the real need for the nurse to evaluate this condition, so interventions can be planned, aiming at the reduction of problems caused by these habits of life.

An item of the instrument considered relevant by the judges was "Did you notice mood changes after the treatment?" $(\mathrm{CVI}=0.88)$, which was present in $35.2 \%$ of participants in the pilot test. In Oncology, the clinical follow-up shows symptoms of anxiety and depression after the diagnostic phase ${ }^{(21)}$, confirming that this is something that needs to be investigated by the nurse in ambulatory care.

Corroborating this claim, a study developed with HNC patients found changes related to dysphoria between 7.3 and $9.7 \%$ during the course of treatment. The authors also emphasize the need for these patients to be evaluated and identified by the health team during the course of treatment, in the nonpsychiatric medical context, allowing the team to assess mental health issues and propose interventions ${ }^{(22)}$.

Another item - "Financial Support" - present in the Roles/ Relationship domain was considered valid by the judges $(\mathrm{CVI}=0.88)$, in line with other instrument validation study also developed in the northeastern region of Brazil for follow-up of non-hospitalized patients ${ }^{(23)}$. Therefore, understanding this aspect is essential, and assisting the family in facing this kind of difficulty does not involve solely the provision of resources, but also guidance about the benefits to those who are entitled and information on ways to obtain them ${ }^{(24)}$.

It was also interesting to find that the judges considered marital status as a significant item to be included in the data collection instrument $(\mathrm{CVI}=1.0)$, reinforcing the finding of an international study, in which married patients had lower probability of presenting metastatic disease and lower propensity to die as a result of their cancer than their unmarried counterparts. And it was also found that, for those who had $\mathrm{HNC}$, the benefit of survival associated with marriage was greater than the benefit of survival published for chemotherapy ${ }^{(25)}$.

It should be noted that the item "weight, height, and BMI", considered relevant by the judges $(\mathrm{CVI}=1.0)$, although it was not 
evaluated in the pilot test due to the lack of a scale in the clinic, was maintained in the final instrument, because HNC patients tend to have dysphagia or odynophagia, both associated with other symptoms, leading to weight loss and low values of $\mathrm{BMI}^{(26)}$.

Other items considered relevant by the judges were "Spirituality/Religion" and "If you have a belief or faith to help deal with the problems" (CVI $=0.88$ and 1.00 , respectively), which can be evidence of the nursing diagnoses Improved willingness for religiosity (00171), Impaired religiosity (00169), and Risk of impaired religiosity $(00170)^{(5)}$.

\section{Study limitations}

As limitations of the study, the exclusion of two domains from the instrument should be highlighted. The justification for not including domain 13 (Growth and development) is that it does not apply to the target population. Domain 6 (Self-perception) was excluded due to its items not reaching the minimum CVI required by the study, and domain 12 (Comfort) was excluded because the judges considered that its items (pain and nausea and vomiting) should be relocated to the "Perception/Cognition" and "Nutrition" domains, respectively. It is recognized, on the other hand, that the revisions are conducted routinely every two years in the systems of classification of nursing diagnoses, and the study would require time to investigate if this change is really effective in the context of healthcare practice. Finally, the judges' definition is hard to be achieved fully. The criterion adopted in the study was that of Fehring, widely used in other studies; however, there is no proof that all the prerequisites are, in fact, guarantee of clinical expertise.

Contributions to the fields of nursing, health, or public policy It is believed that the use of the Instrument for Nursing Investigation by Functional Patterns for Head and Neck Clinic will enable assessing the needs of this type of users, allowing for the planning of individualized interventions. However, it is possible that other demands of adjustments arise in the course of clinical application, since there will be longer time of application and with larger sample.

It is believed that studies in the context of ambulatory care are consonant with international efforts to enhance nursing activities in this specialty. In the Brazilian context, the ambulatory Oncology specialty still lacks studies that seek to improve the nursing practice, aiming at a care based on scientific evidence. It is believed that the development of an instrument for nursing investigation based on functional health patterns and targeted to a specific set of users, in this case, people affected by HNC, is the first step in planning and implementing individualized interventions appropriate to the context.

\section{CONCLUSION}

The instrument construction process was based on the model of functional health patterns, which allowed establishing a correlation with the nursing diagnoses of Nanda-l. The items of the instrument focused on the physical, social, and psychological changes described in the literature with higher probability of being observed in individuals affected by HNC. The validation process resulted in adjustment of the content of the instrument constructed to investigate data of $\mathrm{HNC}$ patients in ambulatory treatment.

This instrument can constitute a valid technology to assist nurses in data collection, since $79.5 \%$ of the items were considered relevant by the judges. In addition, the calculation of global CVI resulted in 0.87 , indicating excellent level of agreement between the judges.

Thus, the conduct of clinical validation is expected in subsequent studies to assess the efficiency of the instrument constructed and validated as a facilitator in obtaining data of patients served in the head and neck clinic.

\section{REFERENCES}

1. Matos LL, Miranda GA, Cernea CR. Prevalence of oral and oropharyngeal human papillomavirus infection in Brazilian population studies: a systematic review. Braz J Otorhinolaryngol [Internet]. 2015 [cited 2017 May 27];81(5):554-67. Available from: http:// www.scielo.br/pdf/bjorl/v81n5/1808-8686-bjorl-81-05-00554.pdf

2. Rigoni L, Bruhn RF, Cicco R, Kanda JL, Matos LL. Quality of life impairment in patients with head and neck cancer and their caregivers: a comparative study. Braz J Otorhinolaryngol [Internet]. 2016 [cited 2017 May 27];82(6):680-6. Available from: http:// www.scielo.br/pdf/bjorl/v82n6/1808-8694-bjorl-82-06-0680.pdf

3. Nemoto RP, Victorino AA, Pessoa GB, Cunha LLG, Silva JAR, Kanda JL, et al. Oral cancer preventive campaigns: are we reaching the real target? Braz J Otorhinolaryngol [Internet]. 2015 [cited 2017 May 27];81(1):44-9. Available from: http://www.scielo.br/pdf/ bjorl/v81n1/1808-8694-bjorl-81-01-00044.pdf

4. Alfaro-Lefevre R. Aplicação do processo de enfermagem: uma ferramenta para o pensamento crítico. Porto Alegre: Artmed; 2010. p.72-117.

5. NANDA-I. Diagnósticos de enfermagem da NANDA: definições e classificação 2015/2017 [Internet]. Porto Alegre: Artmed; 2015[cited 2016 Nov 30]. Available from: http://www.abennacional.org.br/home/Nanda_2015_2017.pdf

6. Cirilo JD, Silva MM, Fuly PSC, Moreira MC. Nursing care management for women with breast cancer in palliative chemotherapy. Texto Contexto Enferm [Internet]. 2016[cited 2017 May 27];25(3):e:4130015. Available from: http://www.scielo.br/pdf/tce/ v25n3/0104-0707-tce-25-03-4130015.pdf

7. Cunha CM, Almeida Neto OP, Stackfleth R. Principais métodos de avaliação psicométrica de validade de instrumentos de medida. Rev Atenção Prim Saúde [Internet]. 2016 [cited 2017 May 27];14(47):75-83. Available from: http://seer.uscs.edu.br/index.php/ 
revista_ciencias_saude/article/viewFile/3391/pdf

8. Brasil. Conselho Nacional de Saúde. Resolução n 466, de 12 de dezembro de 2012. Brasília, DF, 2012 [cited 2017 Jan 30]. Available from: http://conselho.saude.gov.br/resolucoes/2012/Reso466.pdf

9. Gordon M. Manual of nursing diagnoses. Canadá: Jones and Bartlett Publishers; 2010.

10. Medeiros RKS, Ferreira Jr MA, Pinto DPSP, Vitor AF, Santos VEP, Barichello E. Modelo de validação de conteúdo de Pasquali nas pesquisas em Enfermagem. Rev Enferm Ref [Internet]. 2015[cited 2017 Jan 30];4(4):127-35. Available from: http://www.scielo. mec.pt/pdf/ref/vserlVn4/serlVn4a14.pdf

11. Haynes SN, Richard DCS, Kubany ES. Content validity in psychological assessment: a functional approach to concepts and methods. Psychol Assess [Internet]. 1995[cited 2017 Jan 30];7(3):238-47. Available from: https://pdfs.semanticscholar.org/402f/0f1eca4591 39d141eeac5298958fd7557483.pdf

12. Carvalho EC, Mello AS, Napoleão AA, Bachion MM, Dalri MCB, Canini SRMS. Validação de diagnóstico de enfermagem: reflexão sobre dificuldades enfrentadas por pesquisadores. Rev Eletron Enferm [Internet]. 2008 [cited 2017 May 27];10(1):235-40. Available from: http://www.fen.ufg.br/revista/v10/n1/pdf/v10n1a22.pdf

13. Fehring RJ. The Fehring model. In: Carroll-Johson P. Classification of nursing diagnosis: proceedings of the tenth conference of North American Nursing Diagnoses Associations. Philadelphia: JB Lippincott; 1994. p. 55-7.

14. Canhota C. Qual a importância do estudo piloto. In: Associação Portuguesa dos Médicos de Clínica Geral. Investigação passo a passo: perguntas e respostas para investigação clínica. Lisboa: APMCG; 2008[cited 2017 Jan 30]. p. 69-72. Available from: http:// www.apmgf.pt/ficheiros/Investiga $\%$ C3\%A7\%C3\%A30\%20Passo $\% 20 \mathrm{a} \% 20 \mathrm{Passo}$.pdf

15. Sousa Neto VL, Silva RAR, Silva CC, Negreiros RV, Rocha CCT, Nóbrega, MML. Proposal of nursing care plan in people hospitalized with AIDS. Rev Esc Enferm USP [Internet]. 2017 [cited 2017 May 27];51: e03204. Available from: http://www.scielo.br/pdf/reeusp/ v51/1980-220X-reeusp-51-e03204.pdf

16. Silva MM, Silva JA, Esteves LO, Mesquita MGR, Stipp MAC, Duarte SCM. Perfil sociodemográfico e clínico de pessoas em tratamento quimioterápico: subsídios para o gerenciamento em enfermagem. Rev Eletron Enf [Internet]. 2013[cited 2017 May 27];15(3):70412. Available from: https://www.fen.ufg.br/fen_revista/v15/n3/pdf/v15n3a12.pdf

17. Brown DS, Aronow HU. Ambulatory Care Nurse-Sensitive Indicators Series: reaching for the tipping point in measuring nursesensitive quality in the ambulatory surgical and procedure environments. Nurs Econ[Internet]. 2016[cited 2017 Jan 30];34(3):147-51. Available from: https://c.ymcdn.com/sites/www.calnoc.org/resource/resmgr/AAACN NSI Webinar Handout.pdf

18. Martinez K, Battaglia R, Start R, Mastal MF, Matlock AM. Nursing-sensitive indicators in ambulatory care. Nursing Economics [Internet]. 2015[cited 2017 May 27];33(1):59-66. Available from: https://aaacn.org/sites/default/files/documents/news-items/ NursingECARTICLE NursingSensitivelndicatorsinAmbulatoryCare.pdf

19. Testoni RI, Soares VMN, Gonçalves CGO, Kalinke LP. Qualidade de vida de pacientes com neoplasia de cabeça e pescoço: uma revisão integrativa. Tuiuti: Ciênc Cult[Internet]. 2013[cited 2017 Jan 30];47:107-21. Available from: http://www.utp.br/ tuiuticienciaecultura/ciclo_4/tcc_47_disturbios/pdf_47/art_6.pdf

20. Galbiatti ALS, Padovani Jr JA, Maníglia JV, Rodrigues CDS, Pavarino EC, Bertollo EMG. Head and neck cancer: causes, prevention, and treatment. Braz J Otorhinolaryngol [Internet]. 2013 [cited 2017 May 27];79(2):239-47. Available from: http://www.scielo.br/ pdf/bjorl/v79n2/en_v79n2a18.pdf

21. Bergerot CD, Laros JA, Araújo TCCF. Avaliação de ansiedade e depressão em pacientes oncológicos: comparação psicométrica. Psico-USF [Internet]. 2014 [cited 2017 May 27];19(2):187-97. Available from: http://www.scielo.br/pdf/pusf/v19n2/a02v19n2.pdf

22. Fortier ME, Perron T, Fountain DM, Hinic K, Vargas M, Swan BA, et al. Health care in the community: developing academic/ practice partnerships for care coordination and managing transitions. Nurs Econ[Internet]. 2015[cited 2017 Jan 30];33(3):167-81. Available from: https://www.ncbi.nlm.nih.gov/pubmed/26259341

23. Andrade AM, Guimarães AMDN, Costa DM, Machado LC, Gois CFL. Visita domiciliar: validação de um instrumento para registro e acompanhamento dos indivíduos e das famílias. Epidemiol Serv Saúde [Internet]. 2014[cited 2017 Jan 30];23(1):165-75. Available from: http://www.scielo.br/pdf/ress/v23n1/2237-9622-ress-23-01-00165.pdf

24. Amador DD, Gomes IP, Reichert APS, Collet N. Repercussões do câncer infantil para o cuidador familiar: revisão integrativa. Rev Bras Enferm [Internet]. 2013[cited 2017 May 27];66(2):267-70. Available from: http://www.scielo.br/pdf/reben/v66n2/17.pdf

25. Aizer AA, Chen MH, McCarthy EP, Mendu ML, Koo S, Wilhite TJ, et al. Marital status and survival in patients with cancer. J Clin Oncol [Internet]. 2013[cited 2017 Jan 30];31(31):3869-876. Available from: https://www.ncbi.nlm.nih.gov/pmc/articles/PMC4878087/

26. Chavoni RC, Silva PB, Ramos GHA. Diagnóstico nutricional de pacientes do serviço de cabeça e pescoço e sua relação com a disfagia em um hospital oncológico do Paraná. Rev Bras Cir Cabeça Pescoço [Internet]. 2014[cited 2017 Jan 30];43(1):35-41. Available from: http://www.sbccp.org.br/wp-content/uploads/2014/04/Revista-SBCCP-43-1-Artigo-07.pdf 